\title{
AfroBoriqua Mothering: Teaching/Learning Blackness in a Bay Area AfroPuerto Rican Community of Practice
}

\author{
Krista Cortes ${ }^{1}$ \\ University of California, Berkeley, USA
}

\begin{abstract}
This article puts forth the notion of Afroboriqua mothering to understand the types of conditions that allow communal, proleptic practices of blackness to exist within AfroPuerto Rican communities. Afroboriqua mothering is an act that occurs within a community of practice that queers how we understand mothering through activism that always centers blackness and anti-colonial Puerto Ricanness. Through participant-observation and a series of interviews with members of one AfroPuerto Rican community in Northern California, Afroboriqua mothering surfaced as a way to describe teaching and learning (or teaching/learning) within AfroLatinx multi-generational communities that centers blackness as an ancestral, cooperative, and activist practice.
\end{abstract}

Keywords: Afrolatinidad, blackness, mothering, Puerto Ricans, teaching/learning.

\section{Introduction}

Black Puerto Ricans, or AfroBoricuas, ${ }^{2}$ have been telling the masses through compelling prose, poetry, and music about their lives in between black and Puerto Rican, Afro and Latinx ${ }^{3}$, for some time. At this in-between, the seamless existence of afrolatindades allows for the recognition of this identity's numerous presentations, an identity which may or may not conflict with the outside world. Disrupting popular notions of knowledge and identity, AfroLatinx communities present the possibility of reorienting understandings of blackness's materiality away from the epidermalization of blackness (Fanon, 1967; Telles, 2014) and anti-afrolatinidad (Garcia-Louis \& Cortes, 2020) towards conceptualizing blackness as a sociocultural practice - a transformative action that takes place through collective participation in an activity. Looking at the ways AfroLatinx people experience diasporic belonging, research can begin to account for the hybridity and multiple articulations of the phenomenon. With its growing importance in the Puerto Rican diaspora, and AfroCaribbean diaspora more generally, California is a unique and important place to interrogate how blackness is practiced within diasporic AfroLatinx communities (Cortes, 2019).

As "the exemplary communities of the transnational moment," diasporas are a useful starting point from which to consider the formation of community and networks of solidarity

\footnotetext{
${ }^{1}$ Phd Candidate, UC Berkeley Graduate School of Education. E-mail: kcortes@ berkeley.edu

2 This article uses AfroPuerto Rican, Afroboricua, Afroboriqua, and Black Puerto Rican interchangeably to indicate someone of Puerto Rican heritage who readily acknowledges and identifies with blackness. Hyphens are not used in order to emphasize the simultaneous nature of blackness and Latinidad. Additionally, AfroLatinx is used as an identifier that includes AfroPuerto Ricans but is not exclusive to them, including Latinxs who identify as Afro- from other national origins.

3 This article uses the signifier Latinx, opposed to Latino/a or Latin@, to put forth an intersectional view of Latinx people that resists normative gender binaries.
} 
among AfroLatinxs in a global perspective (Tölölyan 1991, p. 5). AfroLatinx diasporic subjects build collectivity across distance through their shared black identity (Brown, 2009; Weheliye, 2009). Despite differing histories and experiences, diaspora exists as "a kind of relation, one between and among counter/parts" where "[p]lace and kinship are interwoven both as bases of difference and as objects of desire, shaping the tenor and significance of the encounter between Black folks here and Black folks there" (Brown 2009, p. 202). That is, beyond the geographical locations people of the diaspora inhabit, there are spaces that traverse the boundaries of land, encompassing shared experiences within and across the diaspora creating a sense of community.

Avtar Brah (1996) refers to this phenomenon as diaspora space, the interstices that exist between and among borders - be they social, cultural, historical or otherwise - and the multiple ways in which subjects occupy these spaces. Yet, we must be cautious when thinking about theses spaces as simply geographical, "referring to physical rather than social locations...there is no actual space that one could call 'the African diaspora,' despite how commonly it is mapped onto particular locales [this] points attention to the ways that social spaces are constructed in tandem with processes of racial formation" (Brown 1998, p 291). Diaspora spaces implicate not only those who have moved or are moving, but also those who have not, simultaneously constructing diasporic and indigenous subjectivity as entangled experiences with implications for AfroLatinx people who often claim both identities (Brah, 1996; Duany, 2001).

Looking at AfroLatinx communities in a transnational perspective forces us to contend with the ways indigeneity is often pitted against blackness (Haslip-Viera, 2001) and Eurocentric understandings of indigeneity that disallow claiming an indigenous identity without the accompanying land roots (Adefarakan, 2011; James, 2019). As Dei (2000) points out, lived indigeneity supersedes birthright, rather it is informed by an "Indigenous inferred epistemology" that is cultivated within communities and passed on from elders to younger generations (Dei 2000, p. 114). Within such a perspective, blackness and indigeneity can exist in unison, since both are "flexibly embedded and embodied" ways of knowing and being (Adefarakan 2011, p 40, italics in original). The diaspora space becomes a site where these tensions become, in a sense, relieved because "the native is as much a diasporian as the diasporian is the native" (Brah 1996, p. 209).

This study focused on one particular diaspora space: the "Bahia Bomba" community located in California's East Bay. "Bahia Bomba" is a bomba dance workshop and community founded in 2014 by queer couple Isla and Lani, that offers classes in bomba percussion, dance, and song. With its intergenerational membership, these lessons are a wellspring of first-hand accounts of AfroPuerto Rican history and culture. Puerto Rican bomba is a musical tradition that emerged on the island after the arrival of trafficked African peoples through the trans-Atlantic slave trade in the sixteenth century (Alamo-Pastrana, 2009). Most generally, bomba is "the spirited interaction between the dancer(s) and the lead bomba drummer" supported through call-and response singing and a percussion ensemble starring barrel drums (Manuel 1994, p. 258). Emblematic of oral traditions in black communities which have been used to preserve and pass on knowledge, bomba dances and drumming rhythms have immense regional variations (Cartagena, 2004). The distinctly African roots of bomba are often overshadowed by its inaccurate description as an African, Taíno, and Spanish cultural fusion (Rivera, 2010). This is a symptom of national discourses that seek to disavow blackness in the racial makeup of Puerto Rico (Godreau, 2015; Rivera, 2007). Contemporary bomba is emblematic of AfroPuerto Rican identity and has become a way for Puerto Ricans to connect and celebrate their Afro-identity and culture on the island and in the diaspora.

Bahia Bomba became a site to explore questions of blackness and afrolatinidad. While is not a study about Bomba, this bomba group created a type of diaspora space where this identity

${ }^{4}$ Bahia Bomba is a pseudonym used to protect the identity of the group. 
work was able to happen. This article focuses on the ways Bahia Bomba exemplifies Afroboriqua mothering - an act that occurs within a community of practice that queers how we understand mothering through activism that always center blackness and anti-colonial Puerto Ricanness. The term itself seeks to embody the lived experience of being black and Puerto Rican by being unhyphenated, using the anti-colonial name for Puerto Ricans - boricuas, and substituting the 'c' for a ' $q$ ' to highlight the queering of roles. Afroboriqua mothering offers a way to describe the teaching/learning within AfroLatinx multi-generational communities that centers blackness as an ancestral, cooperative, and activist practice.

\section{Conceptual Framework}

This study answers the call for more empirical and critical work that pushes back on deficit and individually-oriented explanations of the practices of AfroLatinxs to instead see how families engagement with practices are shaped in complex systems of activity, as well as the ways that communities, through everyday practices and forms of resistance are simultaneously changing, challenging, or accepting the status quo (Collins, 1991; Gutiérrez \& Johnson, 2017; Pacheco, 2012). To do this work robustly I situate the experiences of AfroPuerto Ricans historically, acknowledging the contradictions and tensions that surround blackness as a diasporic, transnational practice. This required a sociocultural perspective, looking at individuals and communities across settings to see the diversity in the ways they practice blackness and the role of space in how blackness gets practiced in distinct places. Sociocultural perspectives, grounded in the work of Lev Vygotsky, center learning within social and cultural processes - joint enterprises between individuals and their communities of practice in which individuals draw on the available tools and resources in their local contexts in pursuit of a goal (Buchter, et al., 2020; Cole, 1996; Halpern, 2018; Kopish, 2016; Lave \& Wenger, 1991; Rogoff, 1990; Saxe, 1999; Vygotsky 1978, 1987; Wertsch, 1998). A sociocultural approach sees learning as occurring in and across multiple cultural contexts imbued with long histories of tool use mediated by language and other semiotic systems towards the end of transformation at the individual and societal levels (Beckett \& Kobayashi, 2020; Nasir \& Hand, 2006). Socio-culturalists see learning and everyday life as entangled phenomena, which should be considered simultaneously in order to develop a robust theory of learning.

Of particular utility to this inquiry into AfroLatinx diasporas and the learning of blackness are the notions of historicity, multi-sited sensibility, and repertoires of practice, which come from a third-generation approach to Cultural Historical Activity Theory or CHAT. Historicity allowed the researcher to place diasporas - their peoples and practices - in historical context, while also attending to their intrinsic hybridity, moving away from pathologizing person-centered explanations of behaviors and essentializing discourses of communities (Gutiérrez \& Rogoff, 2003). To account for varying contexts, a multi-sited sensibility increases awareness of the ways boundary crossings allow for the building and taking up of blackness as a practice. Multi-sited approaches to research also involve being multi-sighted - not only doing work at two or more sites but seeing the field in playful and imaginative ways in order to innovatively pursue queries (Gutiérrez et. al, 2017; Vossoughi \& Gutiérrez, 2014). Coined by Gutiérrez and Rogoff (2003), repertoires of practice describe the varied and collective processes that members of a community participate in commonly over time.

Situating my approach to AfroPuerto Rican communities within a CHAT framework allowed me to see regularities in the organization of the daily lives of families as well as variation in how individuals understand and make sense of the activities in which they participate (Gutiérrez 
and Rogoff, 2003). CHAT as a theoretical tool creates space to study blackness as an everyday practice of AfroLatinx diasporic communities, making visible the connections between the broader network of kinfolk and the reciprocal influence they have on each other in transnational perspectives.

\section{Methods}

The study was anchored by the following question: How do AfroLatinx families design their everyday lives for the teaching/learning of blackness as a practice? In order to answer this larger question, I formulated several sub-questions that related to the projects two distinct parts: (i) LifeHistories of AfroPuerto Rican Families and (ii) Bay Area AfroPuerto Rican Communities of Practice; the focus of this article is on the second part of this larger study. The questions related to the findings presented here are: (a) How do AfroPuerto Rican families in the SF Bay Area create extended kin networks organized around shared understandings of blackness as a practice? and (b) How does the AfroPuerto Rican community of practice design for the teaching/learning of blackness?

Formation and maintenance of an AfroPuerto Rican community of practice in the Bay Area's distinct context has important bearing on how the practice of blackness is taught and learned. In order to document the way this community functioned and its impact on teaching/learning, I spent 10 months as a participant-observer in a bomba class where traditional AfroPuerto Rican music and dance were taught. The class was attended by four of the six focal participants of this study and is a hub of the AfroPuerto Rican community in the area. Through participant-observation in this space, I was able to connect with and learn about the community that has formed around this particular practice of blackness. Following these families across sites allowed me to document the multiplicity and variance in focal families' practices of blackness how blackness travels, is taken up, reorganized, and why - within this extended AfroPuerto Rican community of practice.

Table 1

Participant Demographics

\begin{tabular}{|c|c|c|c|c|c|}
\hline $\begin{array}{l}\text { Focal } \\
\text { Participant } \\
\text { Name }\end{array}$ & Age & Place of Origin & $\begin{array}{l}\text { Number } \\
\text { of Years } \\
\text { in CA }\end{array}$ & $\begin{array}{l}\text { Member of Bahia } \\
\text { Bomba }\end{array}$ & Number of Children \\
\hline Hilda & 44 & Fajardo, Puerto Rico & 20 & Yes & $\begin{array}{l}3 \text { children, ages } 7 \text { months, } \\
5,14\end{array}$ \\
\hline Tamarinda & 34 & Brooklyn, NY & 12 & Yes & 1 child, age 12 \\
\hline Reina & 48 & San Juan, Puerto Rico & 8 & Yes & 2 children, ages 26,29 \\
\hline Alafia & 33 & Queens, NY & 9 & Yes & 1 child, age 4 \\
\hline Milagro & 42 & Vieques, Puerto Rico & 31 & No & 2 children, ages 9,13 \\
\hline Eve & 46 & San Francisco, CA & 46 & No & 1 child, age 10 \\
\hline $\begin{array}{l}\text { Non-focal } \\
\text { Participant } \\
\text { Name }\end{array}$ & Age & Place of Origin & $\begin{array}{l}\text { Number } \\
\text { of Years } \\
\text { in CA }\end{array}$ & $\begin{array}{l}\text { Member of Bahia } \\
\text { Bomba }\end{array}$ & Number of Children \\
\hline Lani & 43 & San Antonio, TX & 12 & Yes & N/A \\
\hline Isla & 41 & Santurce, Puerto Rico & 6 & Yes & N/A \\
\hline Cesar & 42 & Brooklyn, NY & 22 & Yes & 2 children, ages 12,15 \\
\hline Haydee & 38 & Caguas, Puerto Rico & 15 & Yes & 1 child, age 13 \\
\hline
\end{tabular}

Note. All names are pseudonyms. 
The larger study featured six focal participants who self-identified as AfroPuerto Rican and who had at least one child of any age. These individuals also needed to reside in California. It is important to note that participants did not need to appear phenotypically black in the view of the researcher, rather they must explicitly identify as AfroPuerto Rican, however they personally define it. In total the study had six focal participants and four non-focal participants (see Table 1) which met the guideline established for narrative inquiry to reach saturation (Goodson \& Sikes, 2001). Non-focal participants were selected specifically for the second part of the study because they were members of the Bahia Bomba community.

\section{Site Selection}

Northeastern cities such as New York and Philadelphia, are well-known for their Puerto Rican communities but, current trends have Puerto Ricans flocking to lesser-known havens further West and South. California, in particular, has seen a $49 \%$ increase in its Puerto Rican population between 2000 to 2014. These numbers do not account for the unprecedented migration of Puerto Ricans since 2017 due to the fiscal and natural disasters that hit the island. California boasts the eighth largest Puerto Rican population in the US, having over 200,000 residents (Center for Puerto Rican Studies, 2016). The San Francisco Bay area, in particular, is home to 14\% of California's Puerto Rican population (approximately 30,000 people). Even though the SF Bay area does not have a centralized community like the notable "El Barrio" in New York City, the west coast context sets the stage for different and creative ways for enacting Puerto Ricanness and blackness (Hintzen, 2001). Given the prominence of Puerto Ricans in CA and the diversity and variance that exists between the San Francisco Bay Area and previously researched sites concentrated in the Northeast it becomes a useful exercise to consider the experiences of AfroPuerto Ricans in California.

Researcher's statement on positionality. I identify as an AfroPuerto Rican woman and mother invested in raising my son in an environment that affirms his AfroPuerto Rican/AfroCuban roots. While I am now outspoken about my AfroPuerto Rican identity, this was not always the case. Growing up on Long Island I was socialized to be proud of my Puerto Ricanness, but I never explicitly grappled with my racial identity. I first began to interrogate my blackness as an undergraduate student. Living in Washington, D.C. at the time, I found my assertive Puerto Ricanness positioned me as peripheral to the black community. Later, when I moved to Philadelphia, I found a new opportunity to reinvent myself as AfroLatina. I made a concerted effort to make sure people understood that I was black and Boricua and I found that this was the first time I was able to be both. Little did I know that moving to California was going to change all that.

In the Bay area I found that my blackness was accepted and that I could navigate the "black community." What came as a surprise to me was the way I felt my Latinx identity challenged. The venue in which this was most apparent was around language. Spanish was a part of everyday conversations with my new Latinx friends which I was not accustomed to. While they saw Spanish as a way of bringing people in and creating Latinx solidarity I found it to be isolating. Spanish was not the language I felt comfortable using and I also struggled because it was not my Spanish - it sounded different and there were words I had never heard of. I was also confronted with notions of Puerto Ricanness that I did not expect; one Latinx friend, upon learning that I was Puerto Rican said to me "I didn't realize you were Latina at first, but it makes sense because all Puerto Ricans are black". This comment struck me and encapsulates the tensions around Latinidad and blackness that I had been living out. While only scratching the surface of my experiences this statement of 
positionality gives a sense of where I am coming from and the types of experiences that are informing my thinking around afrolatindidad.

\section{Data Collection}

The larger study was designed and implemented to understand how the participant (an adult parent) came to self-identify as AfroPuerto Rican within the socio-cultural context of the San Francisco Bay Area. Through a series of three semi-structured interviews with each participant, I documented (1) the motivations of migration to the Bay Area and how living in this particular space has influenced their evolving understandings of blackness in relation to self over time. I also documented (2) how participants organized their daily lives for the teaching/learning of blackness in their families. All interviews were conducted primarily in English, although Spanish occasionally appeared in participant responses. To better uncover participants' feelings and ideas they each responded creatively to a prompt with drawings, essays, or music. In order to document the ways the AfroPuerto Rican community of practice functioned and its impact on teaching/learning blackness, I was a participant-observer of the Bahia Bomba community and attended Puerto Rican cultural events in the area. My observations were documented in fieldnotes after each observation. Bahia Bomba's weekly class was attended by four of the six focal participants (and all of the non-focal participants) and is a hub of the AfroPuerto Rican community in the area. I also interviewed select non-focal participants about their history of participation in these classes and their membership in the community of practice. Non-focal participants participated in one semi-structured interview which provided additional depth for understanding the dynamics of the Bahia Bomba space.

\section{Data Reduction and Analysis}

Data reduction sought to highlight: (a) the formation of extended family networks/communities of practice, (b) the teaching/learning of blackness as a practice, (c) the historicity of these practices, and (d) the impact of the Bay Area context on the community's sustainability. The units of observation involved participant observation in the classes and events, interviews, and creative descriptions of practices. The units of analysis used in data reduction were the everyday cultural practices of AfroPuerto Rican families and the language and ideologies indexed in those practices. The data analyzed came from the four focal participants and four nonfocal participants who were members of the Bahia Bomba community. All interviews were transcribed using Otter.ai advanced speech recognition software. I re-transcribed sections of transcripts that were particularly apt for addressing the research questions in order to more thoroughly attend to the conventions of discourse analysis useful for making meaning from the data. I reviewed the transcripts, participants' creative writing, and field notes and added researcher comments to each. Part of this review process included writing analytic memos that considered emerging themes in the data and relevant literature that helped me make sense of what I was finding in the data sources. Using MAXQDA coding software, I coded each field text with a coding schema I developed inductively, based on themes that emerged from the data itself, as well as, codes that came from the particular theories in which the project is enmeshed. I also created a thesaurus that defined each code and a frequency table that tracked the number of instances each code appeared in the data set. Coding and data reduction were iterative processes that I re-visited multiple times. 


\section{Findings}

While bomba is at the forefront of what they do, Bahia Bomba is more than just a dance and performance group. "Bahia Bomba is a love story" says Lani, while introducing the group at the 2019 Bay Area Commemoration of El Grito de Lares. Lani continued, describing how Bahia Bomba came about as a result of Isla moving to the Bay Area to pursue a relationship with Lani, "and the rest is history" she says. This focus on queer love is at the heart of how the group is organized and functions. What surfaces through Bahia Bomba's woman-centeredness is the direct confrontation of patriarchal notions of family and traditional gender roles, resurrecting a definition of bomba as a community-based black-boriqua activist practice.

Through participation in the group, observations of performances/events, and various interviews with I was able to document the many and varied ways that blackness was a practice that was fostered and learned within the Bahia Bomba space. One such way this happened was through the practice of Afroboriqua mothering. As explicated above, I coin the term Afroboriqua mothering to describe the ways communities foster blackness, as a learned practice, through their intentional design of space and acts towards both community members and those outside the group. Afroboriqua mothering has three elements: (1) it is a community of black practice, (2) it queers traditional ideas of mothering, and (3) it is motivated by activism that seeks to center blackness as practiced by AfroPuerto Ricans. The following sections will focus on representative moments from the data that support these three areas of Afroboriqua mothering.

\section{A Community of Black Practice}

One component of Afroboriqua mothering is the creation of a community of practice. A community of practice is a group of people that are bound (informally) by their mutual engagement in an activity or practice and the shared learning that occurs in that process (Lave \& Wenger, 1991). Communities of practice self-organize around what people find important, things that matter and have value, and develop communal practices and artifacts that allow them to pursue and maintain particular goals (Lave \& Wenger, 1991). Within the community, those more adept at the use of material/ideational tools or practices apprentice novices towards the acquisition of expertise, subsequently moving them from peripheral to central participation in the community (Lave \& Wenger, 1991). Participation in practices becomes the primary place to analyze learning as it allows researchers to document shifts in the roles and relationships of members within a community of practice which lead to changes in how participants see themselves in their social worlds (Nasir \& Hand, 2006; Packer \& Goicoechea, 2000; Wenger, 1998). Bahia Bomba uses an apprenticeship model of teaching which builds a foundation for students to take risks as learners, giving them the tools to participate - learning by doing. Equally important to their organization as a community is a proleptic understanding of the blackness they practice which situates blackness as simultaneously existing in the present, past, and future.

There are several examples that speak to the community of black practice that has been created by Bahia Bomba which cultivates acts of Afroboriqua mothering. In their weekly class, more experienced members help beginners throughout the three hours of instruction. This is emblematic of an apprenticeship model whereby those with more knowledge of the practice help novices acquire similar levels of expertise. In this way, while Isla and Lani are the teachers in the space, knowledge is distributed and shared in the simultaneous activities of bomba percussion and dancing. I have seen numerous instances of novice drummers seeking guidance from those around 
by sending glances towards group elders when presented with a difficult rhythm. In these moments, assistance is requested in an indirect manner creating opportunities for novices to move from peripheral participation to more central participation as they feel supported by those around them to do so. By organizing teaching/learning such that knowledge is dispersed among students and not held solely by the teacher creates a more egalitarian and equitable learning community. Even the most novice among the group feels valuable and necessary to the functioning of the learning ecology.

I observed countless moments during the dance portion of class that further demonstrate the ways teaching is distributed amongst community members as a means of fostering blackness in this space. For example, more seasoned members are accustomed to helping newcomers put on their skirts and find a spot on the dance floor. There is a great deal of care that goes into helping someone select a skirt to dance in. The skirt plays an important role for the dancer to communicate with the drummer; the skirt needs to have enough length and flow to move and gesture, yet it cannot be too long or unwieldly because then the message will be missed. This understanding of the skirt's purpose is not something that beginner Alafia was familiar with when she took the floor during her first dance class with Bahia Bomba. As she fumbled through the large bag of skirts, grabbing a colorful red and yellow skirt that caught her eye, member Monica came over to assist her. At first Haydee attempted to fashion the skirt around Alafia, folding the top down to account for Alafia's small stature. However, Haydee soon realized that the skirt Alafia had chosen was too large and would not allow her to execute the movements with the ease and fluidness necessary. Haydee removed her own skirt, placing it around Alafia, explaining that she had had this skirt custom made to fit her own height because the other skirts in Isla's collection were too long for her as well. She insisted that Alafia use her skirt as she was learning the movements for the first time, whereas for Haydee, it would be easier for her to wield the longer skirt because she was more familiar with the dances. This vignette exemplifies the varied ways apprenticeship shapes relationships in the class so that all members can share their expertise.

This community of black practice exceeded the technical learning of bomba rhythms, movements, and information, rather for Bahia Bomba, bomba is a way to honor and invoke a rich history in the present. As the lead instructor of dance, Isla consistently reminded the women to dig deep to get in touch with their ancestors and inner strength. In one class I attended, Isla turned to the group saying, "We are all warriors, we are all strong, paso con confianza (step with confidence)." Isla's words reflect both a present and past blackness that lives through bomba; in ushering the past into the present, Isla orients herself and the class towards proleptic understandings of blackness that draw on individual and collective acts of remembering and embodying. To call on one's ancestors is to remember those who have passed on and seek their guidance in daily activities. Seeking out ancestors while dancing suggests that there is wisdom and something to be learned from those who came before us. Similarly, in Isla's affirmation "We are all warriors," she calls on the women to embody a particular strength and stance that is emblematic of indigenous Taína warriors or the Lucumi female warrior goddesses that were worshipped by enslaved Yoruba and Kongolese people in the Caribbean. This is one of many instances that reflects the essence of how the Bahia Bomba community is rooted in the practice of blackness that draws on ancestral understandings of blackness in the present.

In an interview with group member Reina, she shared the ways Bahia Bomba has helped her to develop her black identity. She, like other members, found the teaching/learning of blackness that was happening in Bahia Bomba to exist on a spiritual plane. In discussing her involvement with Bahia Bomba Reina recalled, 
So, I'm singing more coros (choruses), I'm singing more like lead songs and stuff. And then, as I became more interested in the drum, I felt myself getting really good at it in a really short period of time. And, I need to talk to [Lani] about this because it feels weird that I picked this up as quickly as I have. And it's not just because I'm already a musician, it's different. Because it felt like, it felt like I've done it before. If that makes any sense, you know, and so she even made a comment to me, she goes, "maybe you're a descendant of like, cimarrones or like the runaway slaves." She was like, "you have that spirit about you. That makes a lot of sense".

In this excerpt Reina is bringing together a proleptic understanding of blackness with the notion of spirituality. Reina's connection to bomba drumming and her aptitude for it, is described as a spiritual knowing by Lani that crosses the geo-physical and social fields in meaningful ways. In framing Reina as being guided by an embodied cimarrone spirit, Lani suggests a historic blackness existing in the present through Reina's participation in bomba. Lani's assertion allows Reina to reimagine her own blackness as continual, existing beyond the limits of time, evolving from the past into the present and transforming further into the future.

Bahia Bomba's organization of their space and the ethos present in their teaching also brings an ancestral practice of black community into the present. The act of bomba creates avenues that span time and space connecting the ancestors and the present in material and ideational ways that provide for the healing and collective uplift of black folk. The next interview segment continues to draw out the ways Bahia Bomba makes space for this proleptic practice of blackness. Tamarinda reflected,

So, after I started doing bomba more actively, I started dreaming about [my father] more and more and more you know, you know your spirits and your ancestors, they come to you in your dream world. And in these dreams, you know, my dad is happy he's hugging me, he's like real and you know what, I didn't see him that happy since, it was like long before he passed away right? [Bomba] connected me to my biological father, who is the black man in my life you know what Im saying like, [...] he would tell me you know, I like, I like you're wearing your hair natural. I like that you're connecting with your afro-roots. He's like I'm proud of you, I'm happy for you. And so that's really how I know bomba has done something for me that nothing else really could. Because it is ancestral. And it is it is like connecting me to something that was missing. Something that I think has been seeking me as hard as I've been seeking it, and just not understanding what it was. And then, like now, I feel really proud to be a part of the [Bahia Bomba] community. [...] And I'm, like, I ain't going nowhere kids I'm here to stay.

This brings to the surface the holistic work that Bahia Bomba is doing in the community. In this space bomba's blackness is embraced and members are encouraged to engage and interrogate their own blackness through the vehicle of bomba. Bahia Bomba's centering of blackness within the space and lives of their members is in tension with a more mainstream practice 
of bomba. Typically, when bomba's blackness is acknowledged it is attributed to a temporal past, in which the national culture celebrates bomba as a folkloric tradition that brings a type of exoticism to the temporary moment (Arroyo, 2010; Godreau, 2015; Rivera, 2007). Bomba's use of the Kongo dialect in its lyrics and Kongo-derived drumming patterns, coupled with its connection with slave resistance and African spiritual traditions, help define bomba as a markedly black practice (Vega, 1999). Yet as Godreau (2002) warns us, blackness in bomba should not be attributed to anachronistic notions of "black people as happy and rhythmic tradition bearers" who are keeping these practices alive for cultural entertainment (Godreau 2002, p. 283; Alamo-Pastrana 2009, p. 579). Rather, AfroPuerto Ricans use black practices, like bomba, as a source of personal and sociopolitical empowerment (Arroyo, 2010). Through Tamarinda's story we see how Bahia Bomba creates and encourages a type of teaching/learning that requires the concerted effort of a community that is together continually defining and refining blackness as a collective practice.

\section{Queer Mothering}

Afroboriqua mothering builds on the concept of Africana mothering which brings together black feminist understandings of "othermothering" (Collins, 1990) and "black activist mothering" (Gilkes, 1980; McDonald, 1997; Naples, 1992; Sakho, 2017) that acknowledges the political nature of blackness and mothering amongst kinfolk. Historically black families have challenged the assumption that a "family is a cultural unit which contains a husband and wife who are the mother and father of their child or children" (Schneider 1980, p. 33). Rather, for many black people, family includes a diverse network of cultivated familiarity amongst neighbors, co-workers, and friends generated from other venues (religious groups, school, outside-the-home activities, etc.) all of whom work in concert to preserve black life (Foster, 1983; Hays \& Mindel, 1973). In this sense black extended families are multi-generational communities of practice connected through their orientation towards the joint enterprise of sustaining blackness as a practice, through their collective understandings of blackness historically and its continual evolvement in present and future moments.

I add to this queer theory and the work of queer feminists of color who seek to further alter our sense of mothering and family in terms that do not rely on traditional gender roles or binaries. As Gumbs (2016) asks, "[w] hat would it mean for us to take the word "mother" less as a gendered identity and more as a possible action, a technology of transformation that those people who do the most mothering labor are teaching us right now?" (pp. 22-23). To attempt an answer to this question we can look at the work of bell hooks (1994) where she describes the potential of revolutionary parenting which does not place the onus of child-rearing and nurturing on women but positions women and men as equally responsible for the whole child - their physical, emotional, and material needs (hooks, 1994). In this paradigm mothering is not distinguished as unique from fathering, describing women as having entirely different experiences and relationships with children than men, rather revolutionary parenting suggests "a concept of effective parenting that makes no distinction between maternal and paternal care" (hooks 1994, p. 139).

Revolutionizing parenting means queering families and queering mothering (and fathering). To queer these roles mean to disrupt what is considered normal and deconstruct that which is commonplace (Browne 2006; Butler, 1993; de Laurentis, 1991) - in effect to queer social constructions "by disclosing inconsistencies, instabilities, and fluidities of social meanings and boundaries" (Peterson 2014, p. 604). This lens allows for the expression of a politicized identity that is rooted in creating a more socially just world (Duong, 2012). In her essay " $\mathrm{m} /$ other ourselves: a Black queer feminist genealogy for radical mothering," Gumbs (2016) describes queering the idea of mothering and families: 
We say that mothering, especially the mothering of children in oppressed groups, and especially mothering to end war, to end capitalism, to end homophobia and to end patriarchy is a queer thing. And that is a good thing. That is a necessary thing. That is a crucial and dangerous thing to do. Those of us who nurture the lives of those children who are not supposed to exist, who are not supposed to grow up, who are revolutionary in their very beings are doing some of the most subversive work in the world. If we don't know it, the establishment does [...] To answer death with utopian futurity, to rival the social reproduction of capital on a global scale with a forwarddreaming diasporic accountability is a queer thing to do. A strange thing to do. A thing that changes the family and the future forever. To name oneself "mother" in a moment where representatives of the state conscripted "Black" and "mother" into vile epithets is a queer thing. To insist on Black motherhood despite Black cultural nationalist claims to own Black women's wombs and white feminist attempts to use the maternal labor of Black women as domestic servants to buy their own freedom (and to implicitly support the use of Black women as guinea pigs in their fight to perfect the privilege of sterilization) is an almost illegible thing, an outlawed practice, a queer thing. (pp. 20-21)

Imagining the possibility of caring for black children that involves more than one parent, that is community-oriented and gender non-specific is revolutionary and queer - "a good thing...a necessary thing" (Gumbs 2016, p. 20). Bahia Bomba provides a tangible example of what it means to queer mothering, queer families, and expand our views of children from a category based on age to individuals who are learning from and being cared for by others. As a queer, woman of color led group, the group's leaders are intentional about incorporating and accommodating its largely female membership so that mothering becomes a social practice (Dewi Oka, 2016) that is shared. Additionally, Bahia Bomba opens up space for networks of care and opportunities for teaching/learning that are expansive and distributed. These networks span time and space connecting the ancestors and the present in material and ideational ways that provide for the healing and collective joy of black people. The women of the group care for each other as much as they care for the children in the space. The following examples expand on these characteristics.

Many women bring their children with them to classes and performance events. Rather than this causing issues for the flow of class or a parent's ability to learn, I observed how the community was organized in such a way that members did not hesitate to help out. On numerous occasions I witnessed how members rotated care for children so that everyone had an opportunity to participate. During one class a child got antsy and began to cry. The mother, a newer member of the group, sat outside the practice area, nursing the child until they fell asleep. About twenty minutes had passed and it seemed as if the mother was going to miss the rest of the class, but without provocation a member approached the mother, took the sleeping child from the mother's arms and she was able to resume participation in the class. This example is particularly striking because it demonstrates how Bahia Bomba ascribes to an expansive sense of community where even first timers are welcomed and embraced. As Cesar said, "if you are Boricua and live in the 
Bay Area you are part of the Bahia Bomba community even if you have never stepped foot in a class."

The following transcript demonstrates the queering of mothering that happened in the Bahia Bomba space. During one of our interviews, Hilda began to talk about her daughter's involvement with the group,

My daughter... she has a disability and we've had a lot of ups and downs so it's really healing to see that she has this extended family that really loves her, sees her, and her heart. When I began bringing [Lilliana] I was, I was really self-conscious of my little girl like roaming around and, and yeah you know she has this compulsion where she goes up to people and starts looking at them or like, she'll just do whatever she does. And [...] members are just like, that's okay leave her like, she's fine with me, like I'll hold her or, you know [...] like being a mother is incredibly hard and even with a partner you know, I think a lot of women sometimes we do take on a little too much of that parenting role. And so, [...] it's really nice like, you know, you get to have that village to help you parent, yeah. And even like for [Liliana's] birthday, they're like Titis (aunts)...so so I do need them.

This example demonstrates how mothering is not a biological function rather black mothering specifically, reconstructs social relationships between black wo/men, black children, and the greater diasporic black community through practices that support self-definition and black women's empowerment. As Hilda's experience demonstrates, belonging to a supportive community this translates into a practice that is built on self-worth, thriving in our existence, while creating futurities for ourselves and our communities (Dewi Oka, 2016; Gumbs, 2016).

This collective form of mothering extends into performances as well. Bahia Bomba holds a monthly Bombazo or community bomba 'jam sessions' where all members of the community are encouraged to take part in every aspect of the practice - drumming, singing, and dancing. These events are attended by current and past students of Bahia Bomba, others in the area who take interest in Puerto Rican culture or the diaspora of African musical traditions, as well as, passerby on the streets who are lulled by the drums sica or yuba rhythms, energized by the empowering lyrics of the plena, or entranced by skirts flying around possessed bodies at once commanding and being commanded by the drum. I have witnessed numerous instances of children being welcomed into the performance space. For example, a member in the role of bolera (singer) picked up a child in need of comfort while their mother was dancing, gently rocking the child as she continued to sing. In another example, a dancer grabbed hold of a child's hand who was mimicking the dance movements outside the batey circle and brought them into the center of the circle to dance together. These examples demonstrate how mothering is distributed so that it is no one person's responsibility. All members feel comfortable and compelled to provide care and a watchful eye to provide members of all ages with comfort and security within the Bahia Bomba space.

Lani and Isla make sure children as young as two years old have the opportunity to learn through active participation in the percussion and dance workshops. Rather than focus on the technical aspects of the music or dance, I observed how Isla and Lani allowed children to become acquainted with the instruments and movements at their own pace, by watching the adults and other children in the room and replicating the actions. This seemingly simple act is quite powerful because you can see mothers, particularly those of toddlers, become instantly at ease when their child is encouraged to participate freely rather than being scolded because they are not executing 
the techniques properly. This allows these women to more fully participate in the class. It is also not uncommon to see older children entertaining younger children whose interest may have shifted away from bomba to other activities. These forms of help and nurturing most represent the activation of motherlines - intergenerational networks of bloodmothers, othermothers, and women in the community amongst whom support is cultivated and wisdom is shared (O'Reilly, 2000). In making space for children, Bahia Bomba makes space for the women as well, to be their full selves and feel supported while doing so.

This radical, queer notion of mothering exists even when bomba is not the objective. Lani and Isla mother adult members of the Bahia Bomba community through advice and support as well. A recurring theme amongst participants was that Isla and Lani, and the Bahia Bomba community as a whole, was more of a family to them then their blood family. One such example surfaced in an interview with Haydee,

\begin{abstract}
[Isla] will sometimes randomly call just for checkups. She just always wants to make sure everyone in the group is doing okay whether she's seen you in classes or not. If I can think of like when a crisis happens in someone's life they kind of asked the group to kind of surround that person [...] and like, like socially in social media and in their events asking for support. When my husband passed away, the first people I called were [Isla and Lani]. They came to my house and picked me up and drove me to the hospital. They stayed with me the whole time. They helped me get through it. They are my family.
\end{abstract}

This idea of family being there to support you in a time of need is a fundamental aspect of the Bahia Bomba community. Haydee illuminates the ways family is a cultural unit which extends biological ties to those we choose to share our lives with. The support that Lani and Isla offer is not just lip-service but manifests in tangible ways in the lives of those within their community. By creating a space where individuals are allowed to grow at their own volition, with the support of the community, Bahia Bomba becomes more than just a group but a family that extends beyond bomba, becoming an integral part of peoples' lives.

\title{
Black Boriqua Activism
}

Key to Afroboriqueña mothering is a commitment to black activist practice. Similar to notions of black activist mothering (Collins, 1991; Edwards, 2000; McDonald, 1997; Naples, 1992) and political mothering (Fuentes, 2013), Afroboriqua mothering is an intergenerational practice that privileges women although it is not exclusive to women, including individuals of all genders irrespective if they have children of their own, who are fighting for a better life and world for black boricuas, where blackness is always centered and uplifted. Bahia Bomba provides the physical space for AfroPuerto Ricanness to be visible and for connections rooted in black activism to flourish.

Community bomba events (bombazos) point to the black activist ethic that underlies the practices of bomba. The first known documentation of a bombazo was in 1797 (Alamo-Pastrana, 2009). Bombazos offered Puerto Rico's enslaved peoples' opportunities to build community through song and dance while also using it as a tool to develop and organize rebellions against slavery (Alamo-Pastrana, 2009; Díaz Soler 2000, 1994; Baralt 1981). While the exact frequency 
of bomba-masked rebellions is unknown, their impact on the fabric of the colony was reflected in the laws of the time - in 1819 the Reglamento de esclavos was enacted in order to maintain order and discipline. These laws were further expanded in 1826 to explicitly ban the practice of bomba at slave gatherings (Wagenheim \& de Wagenheim, 2008; Rodriguez-Silva, 2012; Arroyo, 2010). This addition to the 1819 laws demonstrates an increased fear of slave rebellion due in part to the spread of bomba across the island (Wagenheim \& de Wagenheim, 2008. Revisiting the question posed by Cartagena (2004), is bomba "a proxy for the past or as a vehicle of expression in the present?", current trends in bomba practice in the diaspora point to the sociopolitical potential of bomba as a catalyst for an AfroLatinx activist identity.

In July of 2019 Puerto Rico was hit with another disaster that went by the name Ricky Roselló. The governor of the island at the time, he came under immense scrutiny after group chats he was involved in were leaked. The 889-page document included homophobic and misogynistic comments and made jokes of those who were killed during the hurricane in 2017. Amid massive public protest across the island and in the diaspora, Roselló resigned from the governorship in August 2019. Bahia Bomba was at the forefront of this struggle in the Bay Area, organizing three different events over a two-week time span - a march around Oakland's Lake Merritt, a protest/demonstration in Oakland's Frank Ogawa Plaza, and a potluck to celebrate the resignation of Ricky Roselló. These events provided Puerto Ricans in the Bay Area an outlet for their frustration, a space to connect with other boricuas, and the opportunity to contribute to this important movement of resistance in Puerto Rico's history. For Puerto Ricans in the diaspora it is often difficult to feel helpful in times of struggle when the island is over 3,600 miles away. Bahia Bomba's commitment to the struggle of Puerto Ricans on the island and in the diaspora is evident in the work they have been doing since their inception. They have used bomba as a healing practice and a call to action that keeps blackness at the core of their social justice activism.

This next example shows the way Bahia Bomba makes activism more than a political expression but a practice of care. As Alafia recalled,

All of these years that I've been in this, been in this state in this Bay Area, Oakland, I find Puerto Rican people trickling into my life. But it was hurricane Maria that really did it. It was like, people all came out to work. Yeah, we all sort of decided like we needed to find each other. We didn't have a choice in the matter. If we were going to get through this thing, we needed to find each other. And, and I can't piece together how I came across these protests, these events. And that's how I met [Isla and Lani] actually, met them at a protest right after Maria. I was, I want to say it was November, downtown Oakland. So, I'm there and they have their bomba drums. And I'm like, "Oh, my God, like this is like spiritual. This is what I've been missing and craving all these years and I can't believe it took a category five hurricane to bring me these people."

This vignette exemplifies the way the Bahia Bomba community harnesses bomba's activist potential, honoring its history by using the practice as both a form of protest and pride. Bomba's roots in slave resistance, freedom, and self-respect, I would argue, also extend into the realm of care. It was an act of radical self-care for enslaved African people to come together to resist their inhumane conditions and actively work to free themselves. This current of black self-care is reflected in the everyday intimacy that marks the interactions, such as the one shared above, and the many relationships that have developed within the Bahia Bomba community. 
The Bahia Bomba community model of activism also extends beyond the black and Puerto Rican communities to include other identity groups that exist at the intersections of race, class, sex, ethnicity, gender, among others. Donning shirts with rainbow colored Puerto Rican flags that bled into black and white representing Puerto Rico's LGBTQ+ Pride and anti-colonial resistance that read "Boricua Lesbians and Friends," Bahia Bomba took bomba to the streets of San Francisco during the 2018 PRIDE parade. The contingent was a massive showing of love for Puerto Rican queerness that honored the work of boricua lesbian elder Ali Marrero-Calderon, who was selected as one of the parade's grand marshals. In the next interview excerpt, Cesar reflects on his experience with this activism,

I think it's, I think it's useful to preserve young people's childhoods, and also have them engaging in activist spaces that are just, that are like organized around them, so that they don't feel like left out, you know, of the conversation or trying to keep up, or not having the information. Either they're bored or they're overwhelmed, you know. And so I took her to the Pride Parade, I thought that was great. To see [Bahia Bomba] and Puerto Rico and our blackness represented you know, I thought that was really, really good. Because like there was a big group marching with them and so we saw like our community plus others who were there to celebrate Puerto Rican LGBTQ Pride. And, and I am just continuing to try and find spaces for her to participate and to lead.

This interview captures just how intimately connected Bahia Bomba is to the local community and its issues; its not a one-off appearance of the group, rather they are a constant presence, always showing up in solidarity when called upon. With their participation they center their AfroPuerto Ricanness in a way that calls people in and makes them feel a part of the community and represented in the action.

\section{Discussion}

In this article I put forth the notion of Afroboriqua mothering as a way to understand the types of conditions that allow communal, proleptic practices of blackness to exist. Through the notion of Afroboriqua mothering I add to the growing literature around afrolatinidad and mothering as a transformative practice. Through an examination of Afroboriqua mothering I position mothers (in all senses of the word) as designers - actors who intentionally organize space and make deliberate decisions about the teaching/learning experiences others will experience (Gutiérrez, 2016). Afroboriqua mother(ing) thusly incorporates the design principles outlined by Gutiérrez (2016) of re-mediation, historicity, equity, resilience, transformability, and sustainability in how mothers approach their teaching and expression of blackness as a practice. These design principles emphasize resilience and change at the individual, collective and ecological levels of the teaching/learning environment in an effort to achieve social and educational transformation (Gutiérrez \& Jurow, 2016). By attending to these principles through their practice of Afroboriqua mothering, participants were able to design for proleptic learning experiences that positioned all members of the community as 'historical actors' with the ability to transform the present and the future (Gutiérrez, 2016; Gutiérrez et al., 2019). 
Mothers also demonstrated how teaching and learning are not separate concepts. Rather, mothers exemplified teaching/learning through their approach to engaging with blackness as both being in the position to instill lessons of blackness to others while also always gaining knowledge about blackness through their varied practices in multi-generational communities. Afroboriqua mothering became one such practice which allowed members of the AfroPuerto Rican diaspora to build community around their shared practice of blackness. Approaching their practices of blackness, specifically as it was done through Afroboriqua motheirng, from a place of novice expertise meant that mothers were always simultaneously learning and teaching. Studying AfroPuerto Rican families' and communities' engagement with blackness as a practice has implications for how we develop other spaces to leverage this knowledge in order to design for black-affirming teaching/learning experiences for AfroLatinx people more broadly.

Bahia Bomba is an exemplar of Afroboriqua mothering, but surely not the only model that exists. Like the transnational, diasporic networks they are a part of, AfroPuerto Rican (chosen) families develop a wide-ranging repertoire of black practices accumulated over generations. The accumulated understanding of blackness promulgated amongst kinfolk, particularly by the women of these extended family networks, highlights the overlap between individual and socio-political understandings of black identity at the level of the everyday. Through participation in a multitude of different practices, individuals navigate between identities they see for themselves, identities they see as available through particular practices, and the identities imposed on them by others. In so doing, members of the community are able to manage their participation by selecting practices that align with their conception of self, avoiding others, and thusly exercising an agentic and transformative disposition towards communal practices of blackness. It is through this active negotiation that blackness becomes a learned practice.

\section{Implications}

Ethnic Studies scholars have seen how Education is a principal arena for the contestation of space, citizenship, identity, and belonging for non-dominant groups in the US (Nieto, 2014; Olsen, 1997). The push for mandatory Ethnic Studies classes in US high schools and the difficulty in developing a curriculum in which everyone feels adequately represented encapsulates the challenges and necessity of doing this work. For AfroLatinx youth, the need for dignity-affirming educational experiences increases daily. Centering AfroLatinx youth in research means recognizing black diasporic subjectivity as entrenched in complex networks of entangled relations that crisscross the globe. Disrupting popular notions of knowledge and identity, AfroLatinx communities offer us the possibility of reconceptualizing diasporic belonging to account for the hybridity and multiple articulations of the phenomenon. Learning from how mothers in this study designed spaces for the learning of blackness sets the stage for future research that specifically focuses on AfroLatinx youth in school settings with the goal of designing educational opportunities that affirm their blackness.

Next steps for scholars will be adopting such an analysis to help transform educational activity systems for AfroLatinx students and design for possible Afro-positive futures. We must be open to looking at the learning of blackness in the diaspora as part of the ingenuity of diasporic subjects as they navigate and adapt to the complex and complicated processes of crossing borders and boundaries. A CHAT framework was important in helping map out this ingenuity in the practices of AfroPuerto Ricans engaged in mothering. CHAT positions researchers to design spaces that allow for reflexivity about the activity and the connected parts, while also creating opportunities to consider the shared object and its necessary reframing to account for the desires of the participants across activity systems, not just within one. This will be an increasingly 
important part of Ethnic Studies research as we consider the role that our work plays in the sustainability and transformation of ideologies, discourse, and practices across and within diasporas towards creating black-affirming spaces for AfroLatinx people.

\section{References}

Adefarakan, T. (2011). Re-conceptualizing 'indigenous' from anti-colonial and Black feminist theoretical perspectives: Living and imagining indigeneity differently. Counterpoints, 379, 34-52.

Alamo-Pastrana, C. (2009). Con el eco de los barriles: Race, gender and the bomba imaginary in Puerto Rico. Identities: Global Studies in Culture and Power, 16(5), 573-600.

Arroyo, J. (2010). "Roots" or the virtualities of racial imaginaries in Puerto Rico and the diaspora. Latino Studies, 8(2), 195-219.

Baralt, G. A. (1981). Esclavos rebeldes conspiraciones y sublevaciones de esclavos en Puerto Rico (1795-1873) [Rebellious slaves conspiracies and uprising of slaves in Puerto Rico (17951873)]. Ediciones Huracán.

Beckett, G. H., \& Kobayashi, M. (2020). A Meta-study of an Ethnographic Research in a Multicultural and Multilingual Community: Negotiations, Resources, and Dilemmas. American Journal of Qualitative Research, 4(1), 85106. https://doi.org/10.29333/ajqr/8267

Brah, A. (1996). Cartographies of diaspora: Contesting identities. Routledge.

Brown, J. N. (1998). Black Liverpool, Black America, and the gendering of diasporic space. Cultural Anthropology, 13(3), 291-325.

Brown, J. N. (2009). Black Europe and the African diaspora: A discourse on location. In D. C. Hine, T. D. Keaton, \& S. Small (Eds.), Black Europe and the African diaspora. University of Illinois Press.

Browne, K. (2006). Challenging queer geographies. Antipode, 38(5), 885-893.

Buchter, J., More, C., Oh-Young, C., \& Stringfellow, J. (2020). Disrupting Norms to Increase Diversity of Teacher Candidates: Restraining Forces for Junior Faculty. Journal of Culture and Values in Education, 3(1), 89-103. https://doi.org/10.46303/jcve.03.01.6

Butler J, (1993). Critically queer. Gay and Lesbian Quarterly, 1(1), 17-32.

Cartagena, J. (2004). When Bomba becomes the national music of the Puerto Rico nation. Centro Journal, 16(1), 14-35.

Center for Puerto Rican Studies. (2016). Puerto Ricans in California, the United States, and Puerto Rico, 2014. The Center for Puerto Rican Studies Data Sheet.

Cole, M. (1996). Interacting minds in a life-span perspective: A cultural-historical approach to culture and cognitive development. In P. Baltes \& U. Staudinger (Eds.), Interactive minds (pp. 59-87). Cambridge University Press.

Collins, P. H. (1990). Black feminist thought: Knowledge, consciousness, and the politics of empowerment. Unwin Hyman.

Collins, P.H. (1991). The meaning of motherhood in Black culture. In R. Staples (Ed.), The Black family: Essays and studies. Wadsworth.

Cortes, K.L. (2019). Between Blackness and Africanness: Indexing Puerto Rican identity through discourse in Northern California. In M.K. Clark, P.W. Mnyandu, \& L. Azalia (Eds.) Pan African Spaces: Essays on Black Transnationalism. Lexington Press. 
De Lauretis, T. (1991). Queer theory: Lesbian and gay sexualities. Differences: A Journal of Feminist Cultural Studies, 3(3), 3-28.

Dei, G. J. S. (2000). Rethinking the role of indigenous knowledges in the academy. International Journal of Inclusive Education, 4(2), 111-132.

Dewi Oka, C. (2016). Mothering as revolutionary praxis. In A. P. Gumbs, C. Martens, \& M. Williams (Eds.), Revolutionary Mothering: Love on the Front Lines (pp. 50-57). PM Press.

Díaz Soler, L. M. (1994). Puerto Rico: Desde sus orígenes hasta el cese de la dominación Española. San Juan: Editorial de la Universidad de Puerto Rico.

Díaz Soler, L.M. (2000). Historia de la esclavitud negra en Puerto Rico. San Juan: Editorial de la Universidad de Puerto Rico. doi:10.108 0/00131725.2014.850980

Duany, J. (2001). Making Indians out of Blacks: The revitalization of Taíno identity in contemporary Puerto Rico. In G. Haslip-Viera (Ed.), Taíno revival: Critical perspectives on Puerto Rican identity and cultural politics (pp. 55- 82). Markus Wiener

Duong, K. (2012). What does queer theory teach us about intersectionality? Politics \& Gender, $8(3), 370-386$.

Edwards, A. (2000). Community mothering: The relationship between mothering and the community work of Black women. Journal of the Association for Research on Mothering, 2(2), 87-100.

Fanon, F. (1967) Black Skin, white masks, trans. Charles L. Markmann. New York: Grove Press.

Foster, H. J. (1983). African patterns in Afro-American family. Journal of Black Studies, 14, 201232.

Fuentes, E. (2013). Political mothering: Latina and African American mothers in the struggle for educational justice. Anthropology \& Education Quarterly, 44(3), 304-319.

Garcia-Louis, C. \& Cortes, K.L. (2020). Rejecting black and rejected back: AfroLatinx college students' experiences with anti-AfroLatinidad. Journal of Latinos and Education. DOI: 10.1080/15348431.2020.1731692

Gilkes, C. T. (1980). 'Holding back the ocean with a broom': Black women and community work. In L. Rodgers-Rose (Ed.), The Black woman (pp. 217-231). Sage.

Godreau, I. (2002). Changing space, making race: Distance, nostalgia, and the folklorization of blackness in Puerto Rico. Identities: Global Studies in Culture and Power, 9(3), 281-304.

Godreau, I. P. (2015). Scripts of blackness: Race, cultural nationalism, and US colonialism in Puerto Rico. University of Illinois Press.

Goodson, I., \& Sikes, P. (2001). Life history research in educational settings: Learning from lives. Open University Press.

Gumbs, A. P. (2016). M/other ourselves: A Black queer feminist genealogy for radical mothering. In A. P. Gumbs, C. Martens, \& M. Williams (Eds.), Revolutionary Mothering: Love on the Front Lines. PM Press.

Gutiérrez, K. D. \& Johnson, P.R. (2017). Understanding identity sampling and cultural repertoires: Advancing an historicizing and syncretic system of teaching and learning in justice pedagogies. In D. Paris \& H. S. Alim (Eds.), Culturally sustaining pedagogies: Teaching and learning for justice in a changing world. Teachers College Press.

Gutiérrez, K. D., \& Jurow, A. S. (2016): Social design experiments: Toward equity by design. Journal of the Learning Sciences, 25(4), 565-598. https://doi.org/10.1080/10508406.2016.1204548

Gutiérrez, K. D., \& Rogoff, B. (2003). Cultural ways of learning: Individual traits or repertoires of practice. Educational Researcher, 32(5), 19-25. 
Gutiérrez, K. D., Cortes, K., Cortez, A., DiGiacomo, D., Higgs, J., Johnson, P., Lizárraga J. R., Mendoza, E., Tien, J., \& Vakil, S. (2017). Replacing representation with imagination: Finding ingenuity in everyday practices. Review of Research in Education, 41(1), 30-60.

Gutiérrez, K., (2016). Designing resilient ecologies: Social design experiments and a new social imagination. Educational Researcher, 45(3), 187-196.

Halpern, C. (2018). Multicultural for who? A review of a comprehensive multicultural textbook. Journal of Culture and Values in Education, 1(2), 58-62. https://doi.org/10.46303/jcve.01.02.4

Haslip-Viera, G. (Ed.). (2001). Taíno revival: Critical perspectives on Puerto Rican identity and cultural politics. Markus Wiener Publishers.

Hays, W. C., \& Mindel, C. H. (1973). Extended kinship relations in Black and White families. Journal of Marriage and the Family, 51-57.

Hintzen, P. (2001). West Indian in the West: Self-representations in an immigrant community. New York University Press.

hooks, b. (1994). Feminist theory: From margin to center. South End Press.

James, W. Y. (2019). Imprint of Racism: White Adult Males' Transformational Experience from Racial Antipathy to Racial Reconciliation. American Journal of Qualitative Research, 3(1), 93-116. https://doi.org/10.29333/ajqr/5813

Kopish, M. A. (2016). Preparing globally competent teacher candidates through cross-cultural experiential learning. Journal of Social Studies Education Research, 7(2), 75-108.

Lave, J., \& Wenger, E. (1991). Situated learning: Legitimate peripheral participation. Cambridge University Press.

Manuel, P. L. (1994). Puerto Rican music and cultural identity: Creative appropriation of Cuban sources from danza to salsa. Ethnomusicology, 38(2), 249-80.

McDonald, K. B. (1997). Black activist mothering: A historical intersection of race, gender, and class. Gender \& Society, 11(6), 773-795.

Naples, N. A. (1992). Activist mothering: Cross-generational continuity in the community work of women from low-income urban neighborhoods. Gender \& Society, 6(3), 441-463.

Nasir, N. I. S., \& Hand, V. M. (2006). Exploring sociocultural perspectives on race, culture, and learning. Review of Educational Research, 76(4), 449-475.

Nieto, S. (2014). Introduction to "diversity, globalization, and education". The Educational Forum, $78,3-6$.

O'Reilly, A. (2000). I come from a long line of Uppity irate black women: African-American feminist thought on motherhood, the motherline, and the mother-daughter relationship. In

A. O'Reilly \& S. Abbey (Eds.), Mothers and daughters: Connection, empowerment, and transformation (pp. 143-59). Lanham, MD: Rowman \& Littlefield Publishers.

Olsen, L. (1997). Made in America: Immigrant students in our public schools. New York, NY: The New Press.

Pacheco, M. (2012). Learning in/through everyday resistance: A cultural-historical perspective on community resources and curriculum. Educational Researcher, 41(4), 121-132.

Packer, M. J., \& Goicoechea, J. (2000). Sociocultural and constructivist theories of learning: Ontology, not just epistemology. Educational Psychologist, 35(4), 227-241.

Peterson, V. S. (2014). Family matters: How queering the intimate queers the international. International Studies Review, 16(4), 604-608. https://doi.org/10.1111/misr.12185 
Rivera, R. Z. (2007). Will the "real" Puerto Rican culture please stand up? Thoughts on cultural nationalism. In F. Negron-Muntaner (Ed.), None of the above: Puerto Ricans in the global era (pp. 217-231). Palgrave Macmillan.

Rivera, R. Z. (2010). New York bomba: Puerto Ricans, Dominicans, and a bridge called Haiti. Rhythms of the Afro-Atlantic world: Rituals and remembrances, 178-199.

Rodriguez-Silva, I. (2012). Silencing race: Disentangling blackness, colonialism, and national identities in Puerto Rico. St. Martin's Press LLC.

Rogoff, B. (1990). Apprenticeship in thinking: Cognitive development in social context. Oxford University Press.

Sakho, J. R. (2017). Black activist mothering: Teach me about what teaches you. Western Journal of Black Studies, 41(1/2), 6-19.

Saxe, G. B. (1999). Cognition, development, and cultural practices. New Directions for Child \& Adolescent Development, 83, 19-35.

Schneider, D. M. (1980). American kinship: A cultural account. University of Chicago Press.

Telles, E. (2014). Pigmentocracies: Ethnicity, race, and color in Latin America. Chapel Hill: UNC Press Books.

Tölölyan, K. (1991). The nation-state and its others: In lieu of a preface. Diaspora, 1, 3-7.

Vega, M. M. (1999). The ancestral sacred creative impulse of Africa and the African diaspora: Ase, the nexus of the Black global aesthetic. Lenox Avenue: A Journal of Interarts Inquiry, 5, 45-57.

Vossoughi, S., \& Gutiérrez, K. (2014). Studying movement, hybridity, and change: Toward a multi-sited sensibility for research on learning across contexts and borders. National Society for the Study of Education, 113(2), 603-632.

Vygotsky, L. S. (1978). Mind in Society. Harvard University Press.

Vygotsky, L. S. (1987). The Collected Works of L. S. Vygotsky: Vol. 1. Problems of General Psychology. Plenum Press.

Wagenheim, K., \& de Wagenheim, O. J. (Eds.). (2008). The Puerto Ricans: A documentary history. Doubleday.

Weheliye, A. G. (2009). My volk to come: Peoplehood in recent diaspora discourse and AfroGerman popular music. Black Europe and the African Diaspora, 120, 161.

Wenger, E. (1998). Communities of practice: Learning as a social system. Systems Thinker, 9(5), 2-3.

Wertsch, J. V. (1998). Mind as action. Oxford University Press.

\section{Notes on Contributors}

Krista L. Cortes is a doctoral candidate at the UC Berkeley Graduate School of Education who positions herself as a scholar of AfroLatinidad and learning with an explicit focus on blackness. She seeks to do research that is consequential and transformative for those who have been historically oppressed and marginalized in university settings. Her larger research agenda takes up the question - what do black-affirming educational spaces look like for AfroLatinx youth? Through her documentation of the teaching and learning of blackness within AfroPuerto Rican communities her work moves scholarship beyond notions of racial performativity and authenticity, towards robust theories of racial learning and identity development. 